\title{
Germ cell tumours: a scary presentation
}

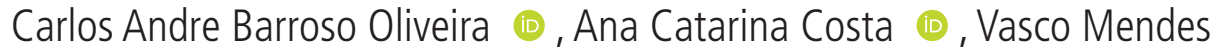

Department of Radiology, Hospital de Braga, Braga, Portugal

\section{Correspondence to}

Dr Carlos Andre Barroso Oliveira;

carlosaboliveira2014@gmail. com

Accepted 12 June 2020

\section{DESCRIPTION}

A 32-year-old patient presented with dyspnoea, fatigue and haemoptysis in the emergency room.

Thoracic radiography was performed and demonstrated a large mass in the left lung. CT was also performed and demonstrated a large heterogeneous mass with cystic component measuring $24 \times 16 \times 14 \mathrm{~cm}$.

CT showed the anteroposterior diameter allowing depth of lesion approach and great vessels deviation (figure 1).

Coronal view (figure 2) and sagittal view (figure 3) allowed better delineation of compression and longitudinal view of the lesion as well as viable lung. These views, specially sagittal (figure 3), allow a more accurate view of bronchi compression.

Biopsy was performed and revealed a mixed germ cell tumour combined with embryonal carcinoma, yolk sac and teratoma.

Tumour markers such as LDH, AFP and $\beta$-hCG were elevated (LDH $700 \mathrm{U} / \mathrm{mL}$, AFP $1.4 \mathrm{ng} / \mathrm{mL}$ and $\beta$-hCG $400 \mathrm{mIU} / \mathrm{mL}$ ).

The patient was treated with a cisplatin-based chemotherapeutic regimen (four cycles of bleomycin, etoposide and cisplatin). Chemotherapy allowed marked reduction of the tumour. Next, the pneumonectomy was performed and histology confirmed a non-seminomatous mixed germ cell tumour (85\% embryonal carcinoma, 10\% yolk sac and $5 \%$ teratoma).

However, the patient is extremely debilitated physically, and the prognosis remains uncertain. During the last appointment, tumour markers were normal.

The mediastinum is centrally located in the thorax and divided into anterior, middle and posterior compartments.

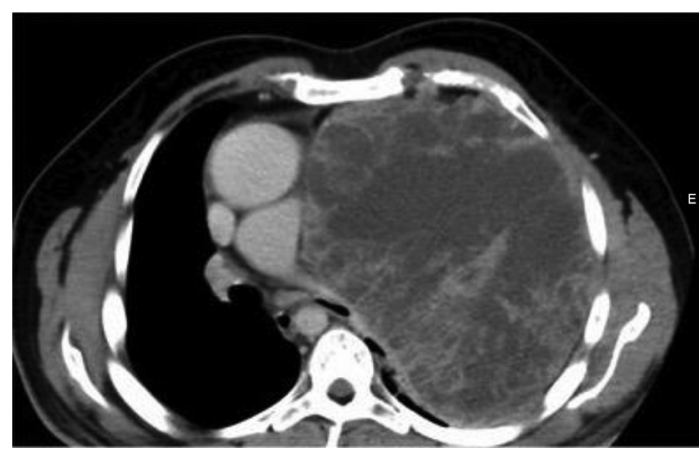

Figure 1 Germ cell tumour. Portal-phase contrastenhanced CT (axial view) shows an heterogenous giant mass occupying most of the left lung measuring $24 \times 16 \times 14 \mathrm{~cm}$. Note the heterogeneous enhancement of the mass.

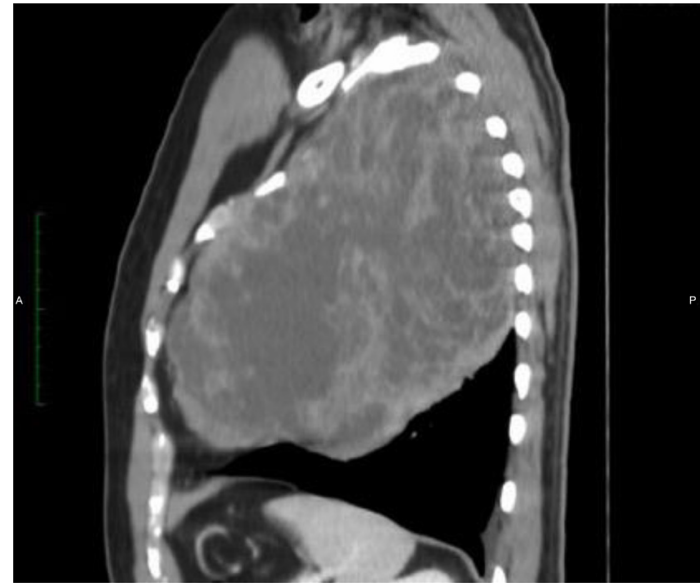

Figure 2 Germ cell tumour. Portal-phase contrastenhanced CT (sagittal view) heterogenous giant mass occupying most of the left lung measuring $24 \times 16 \times 14 \mathrm{~cm}$.

Germ cell tumours comprise 15\%-20\% of all anterior mediastinal masses, occurs in young adults in their second to fourth decade of life, with equal sex distribution. The majority are benign, with teratoma being the most frequently type seen. ${ }^{12}$

Benign teratomas are classified into the following three groups: epidermoid cysts, dermoid cysts and teratomas. Approximately $60 \%$ of teratomas are asymptomatic. $^{1-3}$ The probability of malignancy increases with immature type.

Seminomas are the most common malignant mediastinal germ cell tumour and are located in the anterior and superior mediastinum. ${ }^{12}$ Malignant lesions can present with pain caused by local invasion. $^{34}$

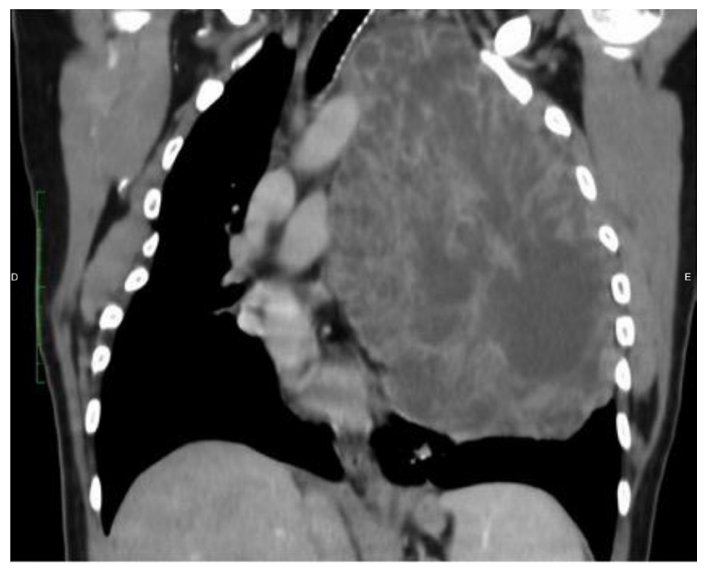

Figure 3 Germ cell tumour. Portal-phase contrastenhanced CT (coronal view) shows an heterogenous giant mass occupying most of the left lung and that causes right deviation of the mediastinum. The mass respects the large vessels margins without invading them. 
Non-seminomatous germ cell tumours are a relative rare group and present a more aggressive behaviour. Approximately $80 \%$ of patients developing these tumours are men. Serum $\beta$-hCG is elevated in approximately $60 \%$ of patients with nonseminomatous germ cell tumours. Elevated alpha-fetoprotein levels are correlated with the presence of embryonic or yolk sac component. $^{12}$

CT usually shows a heterogeneous mass with cystic component, often infiltrative with obliteration of fat planes. ${ }^{124}$

\section{Patient's perspective}

I feel scared for the future. I am very young and afraid to die.

\section{Learning points}

- Contrast-enhanced CT and biopsy play a central role to exclude malignancy of a mediastinal mass.

- Never forget germ cell tumour when a giant mediastinal mass is found.

The risk of malignancy increases in immature types of germ cell tumours.
Contributors $C A B O$ reported the case, selected the images and also talked with a special team for the English language and image review. ACC asked the patient for consentment to publish, helped reporting the $\mathrm{CT}$ and image improvement and selection and also helped with planning. VM supervised all the work and defined the plan to the study as well as analysis of the data.

Funding The authors have not declared a specific grant for this research from any funding agency in the public, commercial or not-for-profit sectors.

Competing interests None declared.

Patient consent for publication Obtained.

Provenance and peer review Not commissioned; externally peer reviewed.

\section{ORCID iDs}

Carlos Andre Barroso Oliveira http://orcid.org/0000-0002-7553-7422

Ana Catarina Costa http://orcid.org/0000-0002-1071-3608

\section{REFERENCES}

1 Fritzsche FR, Kristiansen G, Frauenfelder T, et al. Large mixed germ cell tumor in a young patient presenting as an intrapulmonary mass. Pathol Res Pract 2009:205:572-8.

2 Motzer RJ, Agarwal N, Beard C, et al. Testicular cancer. J Nat/ Compr Canc Netw 2012;10:502-35.

3 Lee $\mathrm{KS}, \mathrm{Im} J \mathrm{G}$, Han $\mathrm{CH}$, et al. Malignant primary germ cell tumors of the mediastinum: CT features. AJR Am J Roentgenol 1989:153:947-51.

4 Ronchi A, Cozzolino I, Montella M, et al. Extragonadal germ cell tumors: not just a matter of location. A review about clinical, molecular and pathological features. Cancer Med 2019;8:6832-40.

Copyright 2020 BMJ Publishing Group. All rights reserved. For permission to reuse any of this content visit https://www.bmj.com/company/products-services/rights-and-licensing/permissions/

BMJ Case Report Fellows may re-use this article for personal use and teaching without any further permission.

Become a Fellow of BMJ Case Reports today and you can:

- Submit as many cases as you like

- Enjoy fast sympathetic peer review and rapid publication of accepted articles

- Access all the published articles

- Re-use any of the published material for personal use and teaching without further permission

\section{Customer Service}

If you have any further queries about your subscription, please contact our customer services team on +44 (0) 2071111105 or via email at support@bmj.com.

Visit casereports.bmj.com for more articles like this and to become a Fellow 